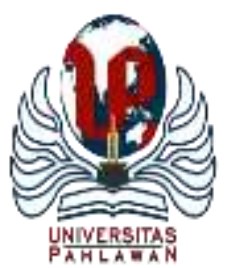

\title{
JURNALBASICEDU
}

Volume 6 Nomor 1 Tahun 2022 Halaman 146 - 156

Research \& Learningin Elementary Education

https://jbasic.org/index.php/basicedu

\section{An innovation of character of Islamic religious studies education towards education 4.0 in Elementary School: Bibliometric Reviews}

\author{
Elihami Elihami \\ Nonformal Education, Muhammadiyah University of Enrekang \\ E-mail: Elihamid72@gmail.com
}

\begin{abstract}
Abstrak
Perkembangan kajian inovasi pendidikan karakter pada pendidikan Agama Islam menuju tantangan pendidikan 4.0 khususnya di Sekolah Dasar melalui kajian bibliometrik dari tahun 2010-2021. Tujuan dari penelitian yakni untuk mengetahui implementasi pendidikan karakter pada peserta didik khsusunya pada sekolah dasar dan mengetahui trend publikasi studi Pendidikan agama Islam di sekolah dasar di era abad ke-21 sebagai upaya mengetahui model terbaru pendidikan karakter secara islami di era digital. Adapun metode penelitian yang digunakan yakni penelitian kualitatif dengan menggunakan analisis aplikasi VOSviewer dalam tinjauan bibliografi yang diambil dari penulis, jurnal, kata kunci, dan referensi kutipan yang paling produktif yang dianalisis mulai dari tahun 2010-2021. Hasil penelitian menunjukan bahwa pemanfaatan dan implementasi pendidikan agama Islam di sekolah dasar belum maksimal karena akhlakul karimah peserta didik belum Islami dan inovasi pendidikan karakter masih jauh dari harapann. Kesimpulan dari penelitian ini bahwa komponen terpenting dalam mengimplementasikan karakter peserta didik secara Islami yang harus dijadikan sebagai prioritas utama dalam menyonsong era pendidikan 4.0 sebagai harapan generasi mileneal yang tangguh dan berkarakter, sehingga dapat berimplikasi dalam mewujudkan perserta didik yang unggul dan memiliki kontribusi dalam model inovasi terbaru yang tidak terlepas dari role model pendidikan karakter pendidikan agama Islam yang terintegrasi pada IPTEKS menuju pendidikan 4.0 khususnya di sekolah dasar.
\end{abstract}

Kata kunci: pendidikan 4.0, sebuah inovasi, studi agama Islam, sekolah dasar.

\begin{abstract}
The development of the study of character education innovation in Islamic education towards the challenges of education 4.0, especially in elementary schools through bibliometric studies from 2010-2021. The purpose of the research is to find out the implementation of character education in students, especially in elementary schools, and to find out the trend of publication of Islamic religious education studies in elementary schools in the 21st-century era as an effort to find out the latest model of Islamic character education in the digital era. The research method used is qualitative research using VOSviewer application analysis in a bibliographic review taken from the most productive authors, journals, keywords, and citation references analyzed from 2010-2021. The results showed that the utilization and implementation of Islamic religious education in elementary schools was not maximized because the students' morality was not yet Islamic, and the innovation of character education was still far from expectations. The conclusion from this research is that the most important component in implementing the character of students in an Islamic way that must be made a top priority in welcoming the education 4.0 era is the hope of the millennial generation who is tough and has character, so that it can have implications for realizing superior students and contributing to the latest innovation models which cannot be separated from the role model of Islamic religious education character education which is integrated into science and technology towards education 4.0, especially in elementary schools.
\end{abstract}

Keywords: education 4.0, an innovation, Islamic religious studies, elementary school

Copyright (c) 2022 Elihami Elihami

$\varangle$ Corresponding author :

Email : Elihamid72@gmail.com

DOI : https://doi.org/10.31004/basicedu.v6i1.1832

ISSN 2580-3735 (Media Cetak)

ISSN 2580-1147 (Media Online)

Jurnal Basicedu Vol 6 No 1 Tahun 2022 


\section{PENDAHULUAN}

Religion is still considered an important part of the moral and ethical formation of students in schools. At least two reasons strengthen this assumption. First, religious educators are the first to be blamed when students make honest mistakes or act outside the limits of good ethics. Religious education subject educators are considered to have failed to teach religion to students. Second, religious subjects become the centre of education in spiritual and social attitudes (Douglass \& Shaikh, 2004). It is indicated by the transfer of full authority to religious educators to assess the two competencies. The granting of this authority is shown by the results of the 2013 Curriculum revision, which was completed in the middle of the year 2016. Management of how to implement the school principal by developing an educational ecosystem that cultivates an efficient, creative, and innovative culture and climate. For updates, strive to improve the character of honest, caring, queueing, confident, and disciplined students as a cultural, character-building, and qualified education. With the implementation of consistent programs, habituation of perfect every day, morning chat activities, topical Qur'an, incentive, and the example of the instructor, the principal's managerial model are very influential in improving the character of pupils.

The central and regional educational reform stakeholders should be more serious about implementing the character education strengthening program; school culture can be leveraged effectively to promote the Social And emotional learning Improvement Program (McCarthy \& Stoszkowski, 2018). Character education is strengthened by incorporating multicultural ideals into the fundamental values of culture and national character. The religious beliefs and ideology of the Indonesian country, which are stated in the purposes of national education, can be used to promote the nation's culture and character education. Character is the most important factor in generating high-quality resources. The character must be created as early as feasible in this manner (Jaya et al., 2019). As a result, the connection between the professors and the pupils is intriguing in cultivating communicative character. Integration in classroom learning, offering genuine instances, habituation, admonishing pupils, spontaneous activity, and role models are all tactics that help to shape the communicative character. Teachers combine with developing closeness between teachers and students in the strategic application of students' character formation. The proximity of professors and students lets pupils feel at ease, allowing them to communicate without feeling awkward (Mashuri \& Suyatno, 2018).

An innovation of Islamic religious studies education towards education 4.0 in Elementary School is very important for priority. As a result, the proximity between the professors and the students is particularly intriguing in cultivating communicative character. Integrating classroom learning, presenting real-life examples, habituation, admonishing classmates, spontaneous activity, and role modelling are all ways that help kids develop a communicative character. Teachers combine with developing closeness between teachers and students in using a strategy for students' character formation. Because of the close contact between professors and students, pupils feel comfortable speaking with them (Hefner \& Zaman, 2007).

The above study shows that innovation in Islamic religious education is centred on inculcating very deep religious values to achieve character building. Previous research only examined the importance of character but has not touched the area of innovation of today's character models. The novelty in this research is the innovation of character education integrated with the development of science and technology. It distinguishes previous research, which is still around the implementation of conventional model character education, which is difficult for the millennial generation. Meanwhile, there has not been much research done on Islamic innovations that are integrated with science and technology, especially in primary school education based on cultural character values, or maybe there are there has been no research related to this before. This study is uniquely presented from improving character education based on the millennial era towards education 4.0. In the Innovation of Islamic Religious Education Curriculum in elementary schools in Facing the Era of Society 5.0. Therefore, this research model is important to prioritize that Islamic values and cultural characters 
(integrated into science and technology) can be perfectly integrated to produce outputs that uphold religion and culture, especially the scope of elementary schools.

On the other hand, the values of Islamic religious education within the scope of primary school education have not been comprehensively implemented in people's daily lives. It was analyzed from the facts that morality crises can be encountered every day. Islamic religious education is one of the important elements to develop good character in an early setting in the elementary school environment in welcoming the era of the industrial revolution 4.0. Based on this phenomenon, this article intends to investigate the innovation of character education in Islamic religious education in elementary schools as one of the elements of the Islamic education curriculum that prepares society for a new era through education 4.0 in the future.

\section{RESEARCH METHOD}

This study employs a bibliographic study design with systematic and explicit mapping methods. In this investigation, a qualitative case study has been used to approach the research to understand how Islamic religious studies education is an innovation of education 4.0 in Elementary School through bibliometric review from 2010-2021, especially in internal documents. A case study is an object to be studied, not a research methodology option; researchers can use various research techniques to study that object. This study uses a qualitative research approach. Semi-structured interviews are used as a data collection tool. The researcher gathers the participants in a WhatsApp group and gives them some guidelines in instructions. It must comprehend the data to the extent that It is familiar with the depth and breadth of the interview and that It continue to re-check the initial audio recordings to maintain the authenticity. The expression would be timeconsuming, frustrating, and progressive; thus, the only good way to familiarize it is with the data. After analyzing the data, the researcher organized it into themes to better understand the pattern. This step reduces some ineffective data in order to highlight the data into the theme. All through the data promoter activity and analysis processes, keep an eye out for clusters or classifications of things that go together. At this point, the researcher should refocus on the examination on a broader level of motifs. Instead focus on codes, a wider level of themes will deliver sorting of code differences become an effective theme by sorting all data extracts so that the code becomes important under the scope of innovation of character of Islamic religious studies education towards education 4.0 in Elementary School through bibliometric review from 2010-2021.

The benchmark of this research activity has been carried out through four stages: 1) the exploration stage; The activities carried out are reviewing the general condition and determining the publication trend data of 250 selected articles in 2010-2021. This study selects the students and teachers who carry out the task of learning Islamic religious education subjects. 2) The stage of preparation and testing of research instruments (Creswell, 2010). The instrument developed consists of two parts which become the main variables, namely teaching resource material and basic competence. 3) survey stage, data collection activities are carried out from data sources determined based on the problem under study. Then the data is processed and analyzed with a content analysis approach. 4) The stage of presenting and drawing conclusions is done by tabulating data based on research problems. Presentation of research results in the form of tables and narratives. Characteristics of data sources or participants are limited by the provision that teachers of Islamic religious education subjects in elementary schools who become data sources are teachers of Islamic religious education subjects. The data collection technique is done by collecting indirect data. In this case, using a questionnaire instrument as a data collection tool. Overall data analysis involves trying to interpret the data in the form of text or images. This discussion will produce recommendations that need to be made based on the real conditions of the research in the context of implementation. 
DOI: https://doi.org/10.31004/basicedu.v6i1.1832

\section{RESULT AND DISCUSSION}

Students in their senior year of high school have the challenge of choosing their career path. It is selfevident that our society will require an increasing number of skilled and specialized engineers in various fields. The purpose of this paper is to describe how we used the knowledge students gained during their two years of studying information and communication technology to tackle a genuine challenge - guaranteeing information confidentiality (ICT). The algorithm was built with the help of three talented students who volunteered to be mentored. As a result, as a final project, we designed an asymmetrical character-level encryption algorithm in the classroom, which we dubbed Azrael. We did not have any scholarships or financing to accomplish the extra work we needed, so we had to rely on our satisfaction from seeing how the various talents were successfully used to address a genuine problem. (Arboledas, 2019). As a result of this finding, we can infer that the instrument built has the necessary technical and pedagogical characteristics to be deemed a unique and significant contribution to the field of geometry education (Sánchez-García \& Cabello, 2016).

Religious character values, accountability, individuality, acceptance, social concern, and environmental care are among the character qualities that develop (Meitriana Mezi \& Jagad Aditya Dewantara, 2020). In recent (Novi Yulianti et al., 2021) explained that planning for character development Includes specific activities relating to religious occasions, group schedules for clean Fridays, homeroom notes sheets, and prizes and penalties for carrying out and not carrying out instruction are all organized in school meetings. Therefore, the topic of character education is both popular and contentious. It is advised to use a psychological approach to comprehending its core constructs (Daniel K. Lapsley \& Darcia Narvaez, 2007). As a result, character development may help students solve problems by stimulating their creative thinking abilities and making the classroom learning process more relevant to real-life situations. (Bramianto Setiawan et al., 2020)

In our country, education is a fundamental value. Education is a crucial basis for a country's development since it allows us to transform a country for the better. Character education can be viewed as an endeavour to build character through education (Julie Nelson Christoph, 2009). Character education is a system that combines knowledge and activities to help students develop moral principles and become wellmannered humans. In Indonesia, we know that character education is highly valued. Character education should begin in primary school since it is difficult to change a person's character if not developed early. Positive universal virtues, such as (1) Wisdom, the power to acquire and use knowledge; (2) Courage, the power to achieve objectives in the face of opposition; (3) Humanity and Love, the power to befriend and care for others; (4) Justice, the power to build society; (5) Temperance, the power to protect against excess; and (6) Transcendence, the power to connect us to a larger universe, can galvanize character education in primary school. Learners' character is meant to be built on the values of universal positive character. (Baihaqi, 2018). Humans make a purposeful effort to establish fundamental intellectual and emotional skills through the process of education. The study suggests an excellent character education strategy for pupils to develop a tolerant and balanced mindset (Ramdhani et al., 2015). Therefore, through cultural values, social philosophy, and religions, approaches to realizing a generation with character can be applied in social education. The religious value, the fair value, the discipline value, the awareness of the environment value, and the obligations are all implied in the children (Widiastuti \& Perbowosari, 2018). And then, character education is strengthened by incorporating multicultural ideals into the fundamental values of culture and national character. The religious beliefs and ideology of the Indonesian country, which are stated in the purposes of national education, can be used to promote the nation's culture and character education (Jaya et al., 2019). Character is the most important factor in generating high-quality resources (Rizal Yusuf Saputra et al., 2021). The character must be created as early as feasible in this manner. 
Implementing industry-based work character development in practical learning to equip students as Zgenerations and determine the feasibility of using industry-based work character-based practice learning methods to increase student learning achievement as Z-generations. Product and learning device evaluation is possible and can be utilized for trials. At the same time, the effectiveness of the designed product can help students learn more effectively (Yuliana, 2018). Therefore, culture and education are inextricably linked. It is a product of human culture and hence becomes ingrained in it. It also aims to change cultural beliefs in order to advance both individuals and communities. The value of exemplary aspects is highlighted by introducing culture-based character education (Murtako, 2015). Character education is strengthened by incorporating multicultural ideals into the fundamental values of culture and national character. The religious beliefs and ideology of the Indonesian country, which are stated in the purposes of national education, can be used to promote the nation's culture and character education. Character is the most important factor in generating high-quality resources. The character must be created as early as feasible in this manner (Mashuri \& Suyatno, 2018).

Implementation of a character-based assessment paradigm is promoted student discipline and achievement (Rusijono \& Khotimah, 2018). Many kids in the new millennium are reliant on the internet, cell phones, television, and social media. It has a significant impact on the development of student personalities since it affects students' lifestyles, ways of thinking, actions, and attitudes. The internet and social media have numerous advantages and disadvantages. It becomes problematic when pupils are increasingly drawn to the unpleasant aspects of life, which destroys their personalities. Students must have positive character strength as a prerequisite for achieving aspirations and becoming good human beings who contribute to the environment. Short movie videos that are related to ideal characteristics that pupils must have to demonstrate positive character values. Honesty, tolerance, discipline, (4) helpfulness, (5) caring for others, (6) responsibility, and (7) courage are some of the qualities that students should possess (Arumsari et al., 2019).

In the creation of characters, several researchers employed problem-solving techniques. All people in the world require IESQ (Intelligence, Emotional, and Spiritual Quotient) development (Erick Ferdiawan and Wira Eka Putra, 2013). So, early childhood education is one component that influences a person's quality. Approaching cultural values is one method to create the fundamental character since the value of culture will always be inherent in human people, no matter where they are. As a result, (Reni Rupita et al., 2021) showed that the principles of discovery learning are well-supported by modern learning theories. The components of the discovery learning paradigm are supported by cognitive learning theory, according to this article. 1) An focus on active learning, 2) the formation of meaningful learning, and 3) the ability to alter attitudes and values toward the topic and the self as a problem solver are three primary aspects of discovery learning that link it to cognitive theory. The result of publishing or perishing Islamic religious studies education in 20102021 is as follows. 
151 An innovation of character of Islamic religious studies education towards education 4.0 in Elementary School: Bibliometric Reviews - Elihami Elihami

DOI: https://doi.org/10.31004/basicedu.v6i1.1832

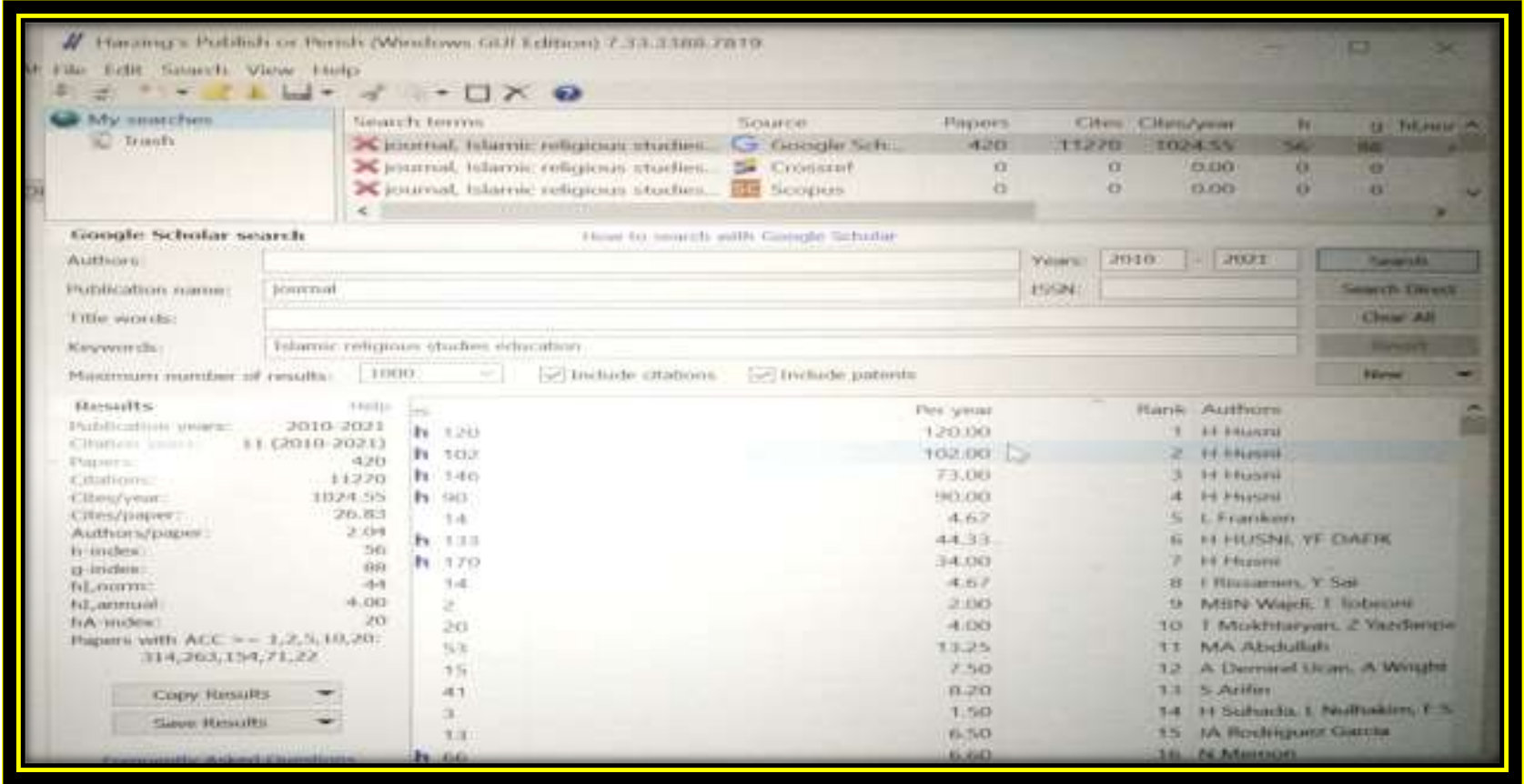

Figure 1. Publish or perish (windows GUI edition) about Islamic religious studies education

The preliminary search results using the Publish or perish (windows GUI edition) 7.33.3388.7819 claim resulted in the term " Islamic religious studies education" appendices, sorted into four terms designated appendices into publication name as journal and Google Scholar database. There were four keywords (Islamic religious studies education is 420 papers.

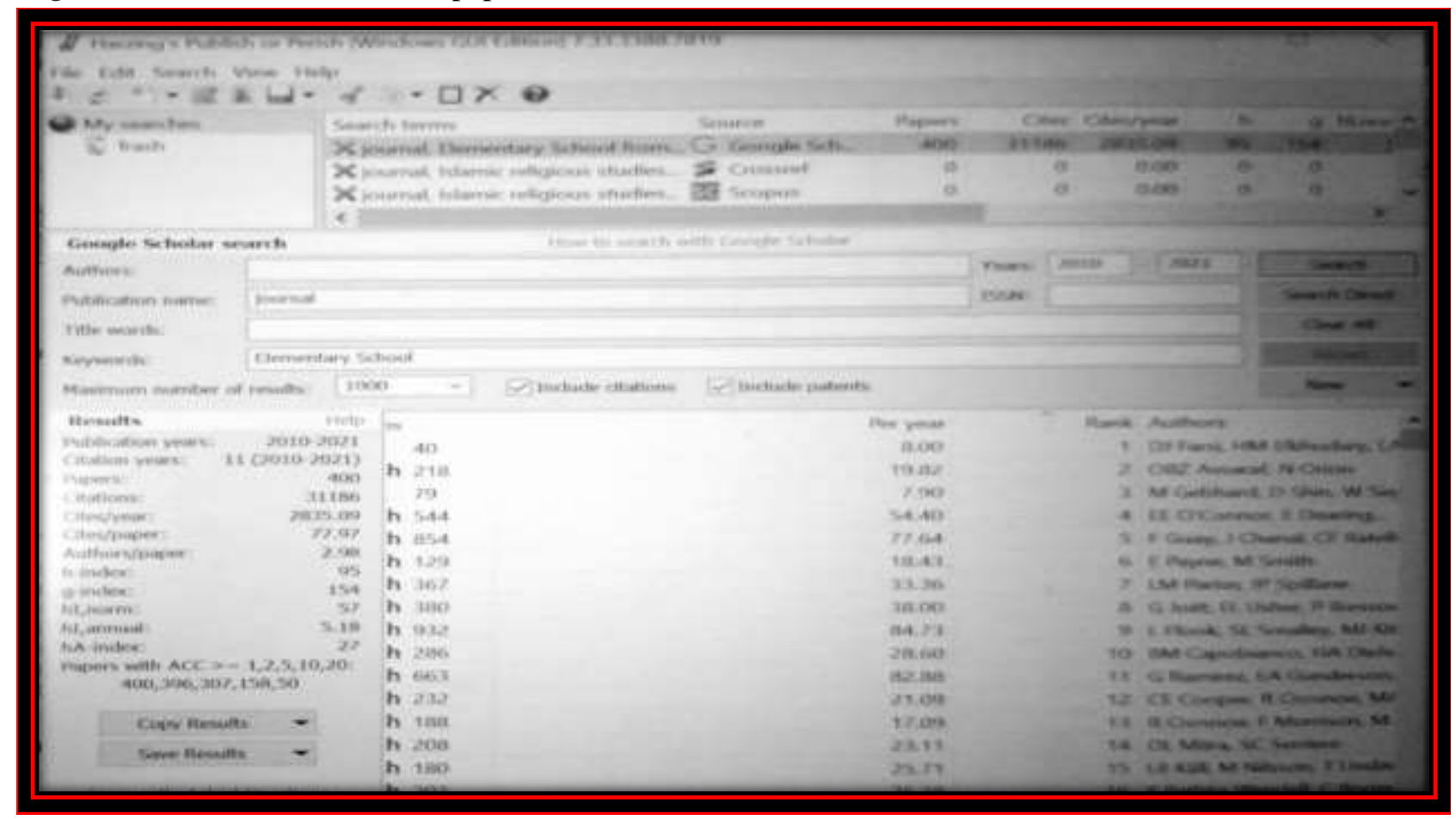

Figure 2. Publish or perish (windows GUI edition) about elementary school

The preliminary search results using the Publish or perish (windows GUI edition) 7.33.3388.7819 claim resulted in the term "elementary school" appendices, sorted into four terms designated appendices into 
152 An innovation of character of Islamic religious studies education towards education 4.0 in Elementary School: Bibliometric Reviews - Elihami Elihami

DOI: https://doi.org/10.31004/basicedu.v6i1.1832

publication name as journal and Google Scholar database. There were four keywords elementary school are 400 papers.

These are the papers most frequently cited by the graph's papers "a corpus-based study on the technical on the technical vocabulary of Islamic Religious Studies". It is usually indicated that they are seminal works in the subject, and it is a good idea to familiarize yourself with them. Picking a prior work will bring up all graph papers that reference it, and selecting a graph paper will bring up all prior work that has been referenced as follows.

\begin{tabular}{|c|c|c|c|c|}
\hline Title & Last Author & Year & Citations & $\begin{array}{l}\text { Graph } \\
\text { citations }\end{array}$ \\
\hline $\begin{array}{l}\text { A New Academic } \\
\text { Word List }\end{array}$ & Averil, Coxhead & 2000 & 2228 & 36 \\
\hline $\begin{array}{l}\text { Is There an } \\
\text { "Academic } \\
\text { Vocabulary"? }\end{array}$ & Polly, Tse & 2007 & 431 & 27 \\
\hline $\begin{array}{lr}\text { A } & \text { nursing } \\
\text { academic word list }\end{array}$ & Ming-Nuan, Yang & 2015 & 77 & 25 \\
\hline $\begin{array}{l}\text { A New Academic } \\
\text { Vocabulary List }\end{array}$ & Mark, Davies & 2014 & 379 & 24 \\
\hline $\begin{array}{l}\text { Establishment of a } \\
\text { Medical Academic } \\
\text { Word List. }\end{array}$ & Guang-Chen, Ge & 2008 & 168 & 22 \\
\hline $\begin{array}{l}\text { ACADEMIC } \\
\text { VOCABULARY } \\
\text { IN } \\
\text { AGRICULTURE } \\
\text { RESEARCH } \\
\text { ARTICLES: A } \\
\text { CORPUS-BASED } \\
\text { STUDY }\end{array}$ & Carolina B., Panza & 2009 & 154 & 22 \\
\hline
\end{tabular}

\begin{tabular}{|c|c|c|c|c|}
\hline $\begin{array}{l}\text { A Basic } \\
\text { Engineering } \\
\text { English Word List } \\
\text { for Less Proficient } \\
\text { Foundation } \\
\text { Engineering } \\
\text { Undergraduates. }\end{array}$ & Jeremy, Ward & 2009 & 141 & 22 \\
\hline $\begin{array}{l}\text { A corpus-based } \\
\text { study of academic } \\
\text { vocabulary in } \\
\text { chemistry research } \\
\text { articles }\end{array}$ & Hossein, Nassaji & 2013 & 63 & 19 \\
\hline $\begin{array}{l}\text { A new medical } \\
\text { academic word } \\
\text { list: A corpus- } \\
\text { based study with } \\
\text { enhanced } \\
\text { methodology }\end{array}$ & Dilin, Liu & 2016 & 78 & 18 \\
\hline $\begin{array}{l}\text { Frequency } \\
\text { Analysis of the } \\
\text { Words in the } \\
\text { Academic Word }\end{array}$ & Yu-Chia, Chang & 2009 & 102 & 18 \\
\hline
\end{tabular}


153 An innovation of character of Islamic religious studies education towards education 4.0 in Elementary School: Bibliometric Reviews - Elihami Elihami

DOI: https://doi.org/10.31004/basicedu.v6i1.1832

List (AWL) and

Non-AWL Content

Words in Applied

Linguistics

Research Papers.

Table 1. a corpus-based study of Islamic religious studies

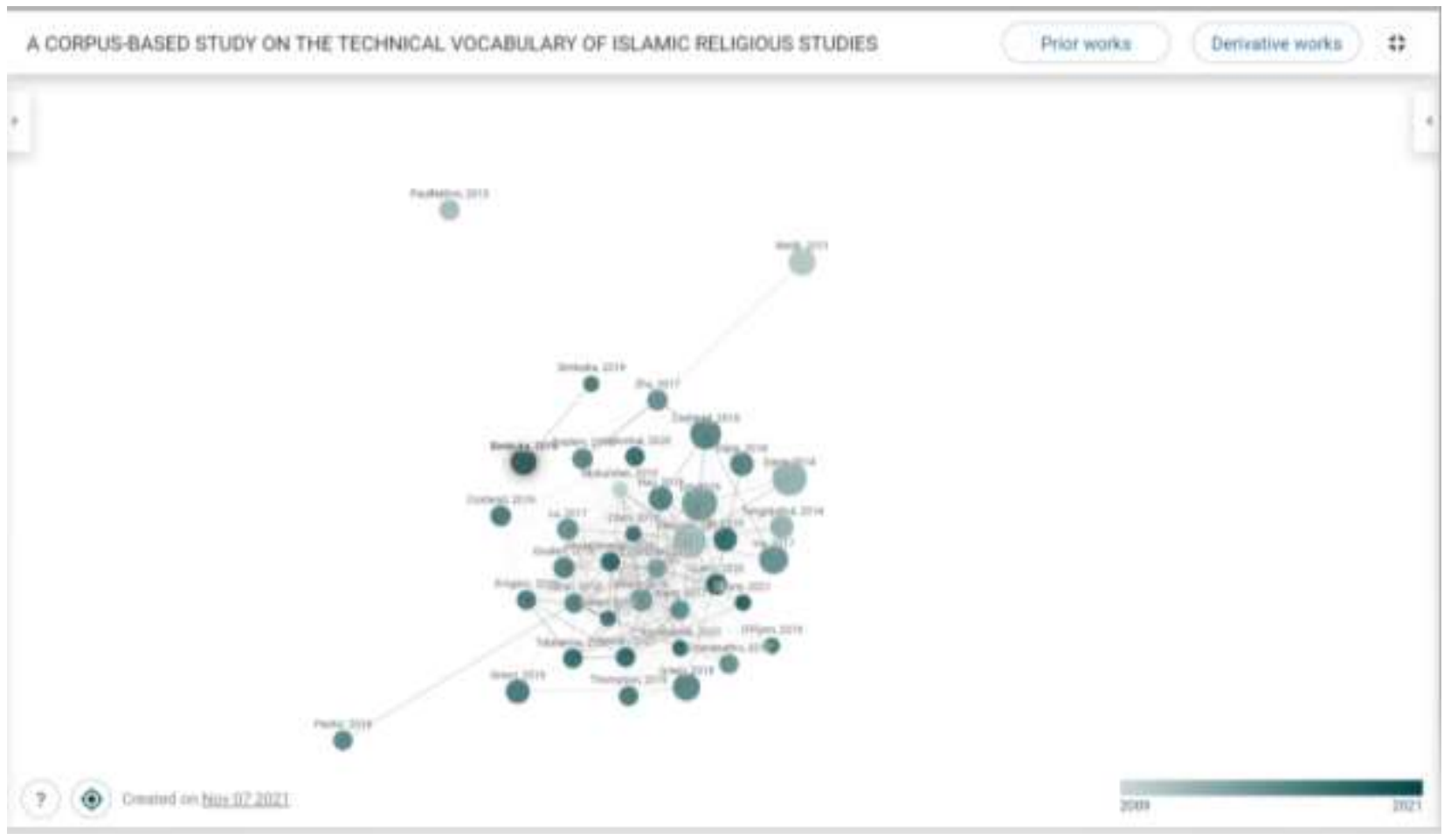

Figure 3. Prior Works about Islamic religious studies

The research outcomes remain presented by writing the processed data of publications in authors in Prior Works about Islamic religious studies using connected papers.

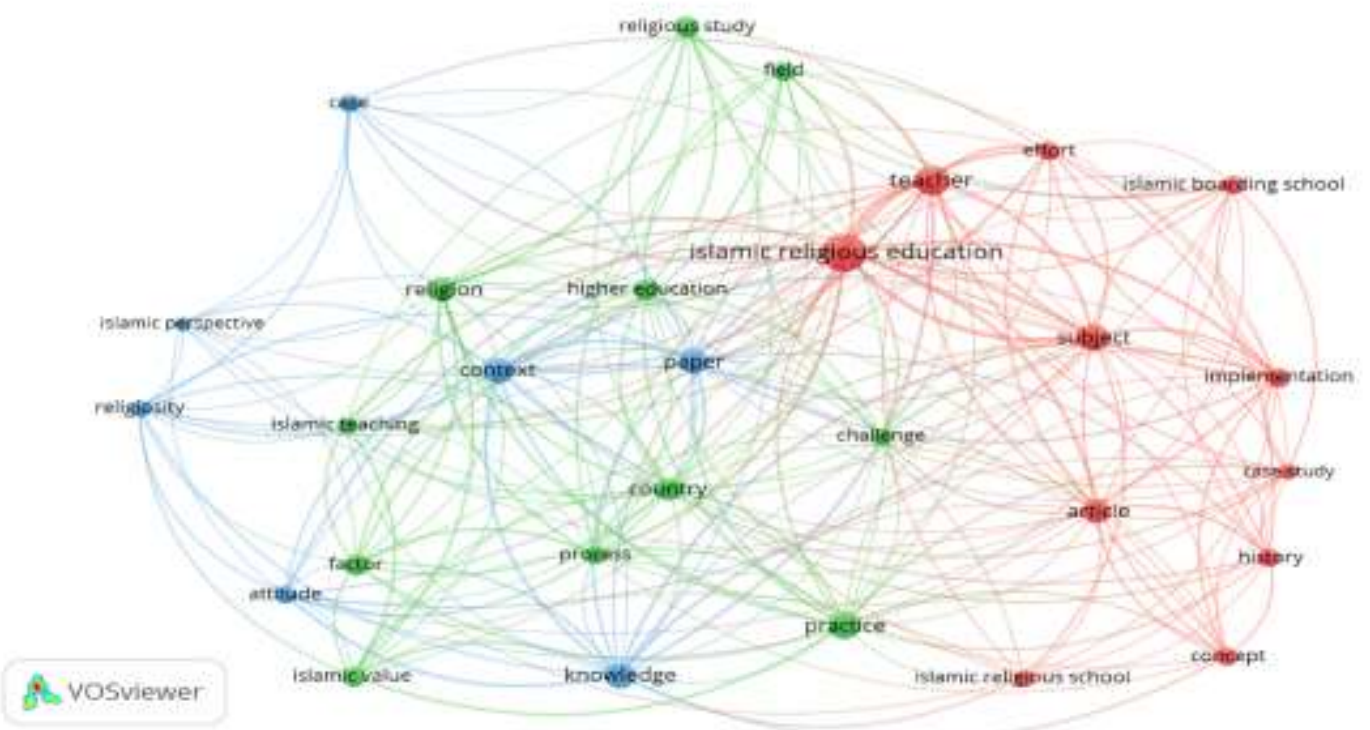

Figure 4. Network Visualization about Islamic religious studies 
The search results using the VOSviewer application yielded 420 bibliographies, which were sorted into 150 selected bibliographies. There were 270 articles in the bibliography that were not selected because they did not meet the criteria set by the researcher. Whereas figure 29 items from three clusters of search result through the VOSviewer application about Islamic religious studies. The first cluster is a case study, article, concept, effort, history, implementation, Islamic boarding school, Islamic religious school, subject, and teacher. The second cluster is a challenge, country, factor, field, higher education, Islamic teaching, Islamic value, practice, process, religion and religious study. The three-cluster attitude, case, context, Islamic perspective, knowledge, paper and religiosity.

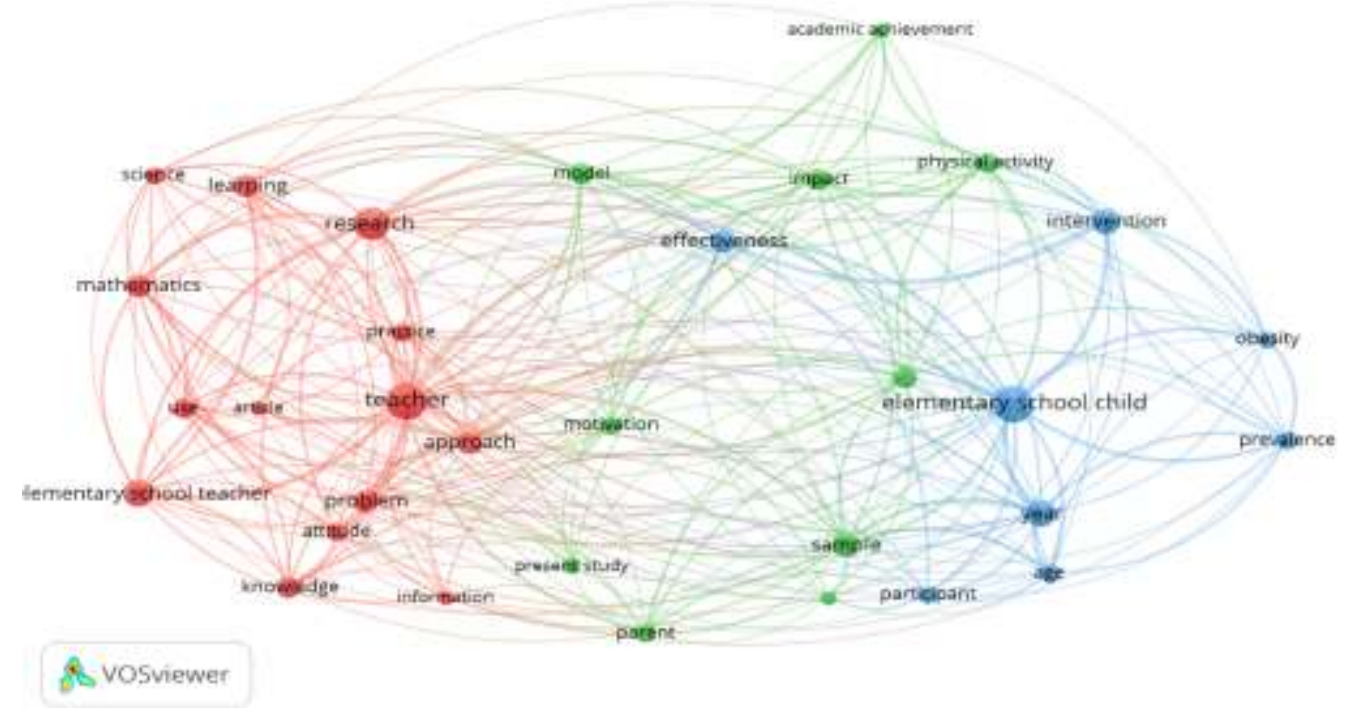

Figure 5. Network Visualization about elementary school

The search results using the VOSviewer application yielded 400 bibliographies, which were sorted into 230 selected bibliographies. There were 170 articles in the bibliography that were not selected because they did not meet the criteria set by the researcher. Whereas figure 32 items from three clusters of search result through the VOSviewer application about elementary school. The first cluster is approach, article, knowledge, learning, practice, and model. The second cluster is impact, association, the current study, impact, motivation, parent, sample and present study. The three-cluster attitude, case, context, Islamic perspective, knowledge, paper and religiosity.

The above research findings show that the publication trend analysis shows that most of the existing character innovations are available as a learning resource on Islamic religious education subjects in elementary schools. The results of previous studies indicate a discrepancy with previous studies. In the innovation aspect of character education, it is conventional in who have fulfilled the curriculum but have not been able to explain the development of the direction of Islamic education, which is integrated with science and technology towards an output-based curriculum, especially innovation of character education in elementary schools. It should be noted that the teaching material in Islamic religious education learning in elementary schools is knowledge that is not philosophically bound as a particular discipline of knowledge as social studies. Knowledge learned in the eye. Islamic religious education lessons in the form of factual knowledge, conceptual, procedural, and metacognitive. From this aspect, what needs to be done in learning is actualizing knowledge with up-to-date social information and facts from the material needs of Islamic Religious Education.

The processed results and analysis of VOSviewer and Connected paper data are discussed from the point of view of character education innovation and Islamic religious education to encourage the achievement 
of the implementation of character education innovations towards the challenges of education 4.0. The research has limitations because it still reviews the VOSviewer application data and Connected paper with a mixed Google Scholar and Scopus indexation model. Researchers hope that in the future, there will be research that examines research data that discusses character education innovations in Islamic religious education, specifically indexation data on Scopus data and the Web of Science.

\section{Acknowledgement}

Many thanks to the Muhammadiyah Organization, especially leaders of the Muhammadiyah University of Enrekang, who have helped a lot in technique and method until this article was published.

\section{Conclusion}

Religious character, discipline, and autonomy are all being cultivated through schooling. Habit development, modelling provided by the principles and students' supervisors, and students' motivation building are all utilized to create students' characteristics through bibliometric review from 2010 to 2021 , an innovation of the character of Islamic religious studies education towards education 4.0 in elementary school. The retrieved bibliographic review is analyzed using the VOS viewer tool. The most productive authors, journals, keywords, and citation references are all investigated. In the years 2010-2021, the rate of relative growth and the time necessary to double were computed. The boarding school then discovered interaction between and interaction among students. Those three are examples of associative social interactions, which entail cooperation in developing a student's character in elementary school.

\section{References}

Arboledas, D. (2019). A New Character-Level Encryption Algorithm: How To Implement Cryptography In An Ict Classroom. Journal Of Technology And Science Education. Https://Doi.Org/10.3926/Jotse.491

Arumsari, C., A, N. H., \& Isti'adah, F. N. (2019). The Ideal Character Of Students Based On Moral Values In Short Movie Videos. Journal Of Physics: Conference Series. Https://Doi.Org/10.1088/17426596/1179/1/012097

Baihaqi, M. (2018). Building Character Education In Basic School By Positive Virtues Universal. Https://Www.Semanticscholar.Org/Paper/7b29bcd569ca59e81bff4137375d83e593db644f

Creswell, J. W. (2010). Research Design Pendekatan Kualitatif, Kuantitatif, Dan Mixed. Yogyakarta: Pustaka Pelajar.

Douglass, S., \& Shaikh, M. (2004). Defining Islamic Education: Differentiation And Applications. Current Issues In Comparative Education, Https://Semanticscholar.Org/Paper/F20a9065e1456e99c61c0d52bedc3334833c2eae.

Ferdiawan, E., \& Putra, W. E. (2013). Esq Education For Children Character Building Based On The Philosophy Of Javanese In Indonesia. Procedia-Social And Behavioral Sciences, 106, 1096-1102.

Hefner, R., \& Zaman, M. (2007). Schooling Islam: The Culture And Politics Of Modern Muslim Education. Https://Semanticscholar.Org/Paper/0967c926aa80a7ad52bf1e42c51a5e14b5c0cbf8

Jaya, D. R., Sauri, S., Muchtar, H. S., \& Warta, W. (2019). Strengthening Student Character Education Through Investing Multicultural Values In Madrasah. International Journal Of Nusantara Islam. Https://Doi.Org/10.15575/Ijni.V7i2.12587.

Lapsley, D. K., \& Narvaez, D. (2007). Character Education. Handbook Of Child Psychology, 4. 

Elementary School: Bibliometric Reviews - Elihami Elihami

DOI: https://doi.org/10.31004/basicedu.v6i1.1832

Mashuri, R. S., \& Suyatno, S. (2018). Teaching The Students In Order To Be More Communicative In Elementary School. Https://Www.Semanticscholar.Org/Paper/Daf36d7771fdfe8dc479e88c65d0a44e43997c5c

Mccarthy, L., \& Stoszkowski, J. (2018). A Pedagogical Approach To Coach Education: What Worked For One Particular Hearner, How Why. Https://Www.Semanticscholar.Org/Paper/800b47d25c0f28b0a794576e150836740d608c76.

Mezi, M., \& Dewantara, J. A. (2020). Implementation Of Character Education In The Student Council. Jurnal Basicedu, 4(3), 765-774.

Murtako, M. (2015). Culture-Based Character Education In Modernity Era. Ta'dib, 20, 149-164. Https://Doi.Org/10.19109/Td.V20i1.326

Nelson Christoph, J. (2009). Each One Teaches One: The Legacy Of Evangelism In Adult Literacy Education. Written Communication, 26(1), 77-110.

Ramdhani, M., Jamaluddin, D., \& Ainissyifa, H. (2015). Building A Moderate Attitude Through Character Education. Https://Www.Semanticscholar.Org/Paper/9f1a23770463f182d2e93402c7032b35a449e550

Rupita, R., \& Dewantara, J. A. (2021). Establishing The Character Of The Civil Services Learning Discipline As Students Civic Virtues. Jurnal Civic Hukum, 6(2).

Rusijono, \& Khotimah, K. (2018). The Implementation Of An Assessment Model Based On Character Building To Improve Students' Discipline And Achievement. Https://Doi.Org/10.1088/1757899x/296/1/012040

Sánchez-García, A., \& Cabello, A. B. (2016). An Instrument For Measuring Performance In Geometry Based On The Van Hiele Model. Educational Research Review, 11, 1194-1201. Https://Doi.Org/10.5897/Err2016.2801.

Saputra, R. Y., Kurniawan, S. B., Rintayati, P., \& Mindrati, E. (2021). Jurnal Basicedu. Jurnal Basicedu Vol, 5(2).

Setiawan, B., Rachmadtullah, R., \& Iasha, V. (2020). Problem-Solving Method: The Effectiveness Of The Pre-Service Elementary Education Teacher Activeness In The Concept Of Physics Content. Jurnal Basicedu, 4(4), 1074-1083. Doi: Https://Doi.Org/10.31004/Basicedu.V4i4.484.

Widiastuti, K., \& Perbowosari, H. (2018). Character Education Value In The Nagendra Tradition In Piodalan At Penataran Agung Temple. Vidyottama Sanatana: International Journal Of Hindu Science And Religious Studies. Https://Doi.Org/10.25078/Ijhsrs.V2i2.624

Yuliana, H. (2018). Counting Of Z-Generation With The Development Of Work-Based Characters In Practices Learning. Taman Vokasi. Https://Doi.Org/10.30738/Jtv.V6i2.4149.

Yulianti, N., \& Yusrizal, N. U. (2021, September). Principal Management In Strengthening Character Education. In 2nd International Conference On Science, Technology, And Modern Society (Icstms 2020) (390-394). Atlantis Press. 